\title{
Pathways and Obstacles to eParticipation at the European level
}

A comparative analysis of the European Citizens' Consultation 2009 and the online consultations of the European Commission

\author{
Romain Badouard \\ COSTECH Lab, University of Technology of Compiègne, romain.badouard@utc.fr
}

\begin{abstract}
Since the early 2000's, the European Institutions have set up several eParticipation projects. These projects are embedded in different political strategies and are managed by different actors within the institutions. This leads to a wide variety of projects and prevents the European Union developing a single and concerted strategy in terms of online participation.

This paper intends to compare two different models of online consultation: the Commission consultations hosted on Your Voice in Europe, and the European Citizens' Consultation 2009. The paper tackles three main subjects: the institutional strategies which frame these sites; the actors that they mobilize; their main and collateral effects. The goal of this synthesis is to identify some key features that fit the European context, in order to assess the possibilities of sustainability of such political experiments.
\end{abstract}

Keywords: eParticipation, European Union, Online consultation, Civil society organizations, Online activism

Acknowledgement: The data concerning the European Citizens' Consultation (ECC) have been collected in the course of a collective research project involving scientists from different European universities, with which I have been able to collaborate. I wish to thank here Raphaël Kies (Université du Luxembourg) and Stéphanie Wojcik (Université Paris-Est Créteil), who were responsible for the analysis of the role of online forums in the ECC arrangement, for having made this data collection possible.

n the context of European institutions, eParticipation projects have not been developed in the framework of a single concerted strategy. From the late 1990's onwards, the Commission, the

Parliament and the Council have developed their own online participation mechanisms (Dalakiouridou, Tambouris \& Tarabanis, 2009). Even within the European Commission, eParticipation projects are managed by various Directorates-Generale (DGs).

The first online participatory procedures developed by the Commission were indeed introduced in the early 2000's, in the wake of the publication of the White Paper on European Governance. The use of information and communication technologies was seen as a way to promote better involvement of civil society in the decision-making process.

From 2004 onwards, the Commission's DG Communication took up the question. In order to face up to the "democratic deficit" which affected the institutional legitimacy, channels of two-way online communication were set up, in order to allow citizens to make their voices heard on the European stage.

At the same time, public policy related to the development of a "knowledge society" took a significant turn. Whereas this policy, since the beginning of the 1980's, had been primarily focussed on economic and technological issues, the i2010 eGovernment Action Plan (2006) was directed at the development of new technologies which favour citizen participation, identified as a major issue in an inclusive and democratic "knowledge society". 
The development of eParticipation projects within the Commission is thus based on three main pillars: the policies related to the reform of the European governance, the modernization of institutional communication and the democratization of the "knowledge society". This wide variety of strategies leads to heterogeneous projects, which call on various actors and put into practice different models of European citizenship. In this paper, I propose to give an idea of this diversity by taking as examples two online consultation mechanisms which have very different characteristics:

- the online platform European Citizens' Consultation (ECC), which functioned from December 2008 to June 2009 in all the Member States of the European Union;

- the site Your Voice in Europe, which hosts the consultations carried out by the various Commission's Directorates-General since 2001.

I will address three dimensions: the institutional strategies which frame these sites; the actors that they mobilize; their main and collateral effects.

By comparing these two models of online participation, I seek to identify features that fit the european context, to the extent that they are the conditions of the sustainability of these participatory mechanisms.

\section{Online consultations of the Commission: a policy instrument}

\subsection{The Interactive Policy Making and the normalization of the Commission consultation procedures}

The publications of the White Paper on Reforming the Commission (2000) and the White Paper on European Governance (2001) were followed by the renewal, or the creation, of a number of different sites: the new Europa and Eur-Lex platforms which allow free access to a wide variety of documents related to European politics; the creation of the sites Dialogue with Business and Dialogue with citizens which aim at providing an interactive response to more targeted enquiries; and also the upload of reports and minutes of the meetings onto the sites of the Parliament and the Commission.

Amongst these various initiatives, one is particularly noteworthy: Interactive Policy Making (IPM). IPM is an information system which facilitates the management of questionnaires online. It was developed in 2001 by the Commission's Directorate General for Informatics (DIGIT), and has since been used in different contexts. The best known application of the IPM is Your Voice in Europe, ${ }^{1}$ which hosts the Commission's consultations.

The use of the IPM by the Commission leads to a standardisation of its consultation procedures. All the consultations carried out by the various DGs are centralized at the heart of Your Voice in Europe. On its home page are posted all the various consultations to which the "interested parties" can reply online. The types of public aimed at, as well as the agenda for the unfolding of the consultation, are clearly stated. The aim of the Commission is to carry out the widest possible consultation on its policies, targeting specific sectors of the public on specific topics, and questioning them upstream of the legislative process. The subject of these consultations is indeed defined with a view to a specific policy to come, in order to allow the "interested parties" to influence its general objectives, its method of deployment, its performance indicators, and extending to the first broad outline of this policy. All these features are guaranteed by the General principles and minimum standards for consultation of interested parties by the Commission, which were published in 2002. This document not only normalizes the consultation procedures but it gives them an institutional recognition and inserts the IPM into a network of governance tools. It is thus conceived as a policy instrument, in the way it is defined by P. Lascoumes and P. Le Galès

\footnotetext{
${ }^{1}$ http://ec.europa.eu/yourvoice/
} 
(2004), i.e. a socio-technical arrangement which aims at deploying a public policy by organizing a mediation between political actors. This institutional recognition of the IPM also appears to favour its durability: between 2001 and 2008, 156 consultations were carried out on Your Voice in Europe.

\subsection{Reconciling inclusion and efficiency of the decision making process}

With IPM, the Commission aims to deploy a three-part strategy. First, it is a question of opening expertise and lobbying practices at the European level. Lobbying and expert hearing are longstanding practices in Brussels. By bringing the consultations to a single place and making them public, the Commission intends to open these practices to the greater public, as "ordinary" citizens can take part into these processes. But more than simply broadening the participation, Your Voice in Europe suggests that it is possible for a citizen to be heard by the Commission on specific issues. Thus, it is also a tool for staging the democratization of the European Union.

Secondly, it is indicative of an evolution of the relationships between the Commission and civil society organizations. Following the publication of the White Paper on European Governance, the data base CONECCS was constructed for the purpose of listing the organizations that are suitable partners for the Commission. In the context of the European Transparency Initiative, it was replaced by a Register of Interest Representatives, ${ }^{2}$ where organizations that intend to participate in a specific consultation are invited to subscribe. This register is public, and any web user can have access to it. The contributions that are sent to the Commission are also made public on the specific pages of the consultation. In this regard, Your Voice in Europe is a way of regulating lobbying at the European level, by putting standards for consultation into practice, and by making public the identity and the contributions of the participants.

Then, with its consultations, the Commission also intends to mobilize fresh sources of expertise (Saurugger, 2006). As most of the European civil society organizations that interact with the Commission are in Brussels, putting the consultation procedures online is a way of mobilizing new organizations all over Europe. That enables the Commission to have access to a larger amount of advice on a specific topic. It also enables impact analysis by measuring the popularity of a future initiative by those first concerned, and all this at a lower cost. The site is thus related to a strategy of making the consultation procedures more efficient and more profitable.

Your voice in Europe stages a democratization of the $\mathrm{EU}$, regulates the relationship between the Commission and lobbies, and favours a more effective consultation process. It appears to be a means of democratizing the decision-making process, and a tool for improving its efficiency. Yet, at the European level, openness and efficiency of the decision-making process are often opposed as incompatible features. F. Scharpf (1999) distinguishes what he calls input legitimacy, that can be considered as a register of democratic legitimation (the $\mathrm{EU}$ is legitimate because its action results from the expression of a general will) and output legitimacy, which is related to its efficiency (the $\mathrm{EU}$ is legitimate because it can tackle transnational problems). The Commission consultations can therefore be seen as an attempt to render compatible these two means of legitimation, as there are conceived as democratic and efficient tools (Bouza Garcia, 2009).

The consultation process carried out by Your Voice In Europe is specific, as the site is part of a triple strategy which mixes democratic and efficiency stakes. It benefits from an institutional recognition, and puts into practice a model of participation linked to expertise and lobbying.

\footnotetext{
${ }^{2}$ https://webgate.ec.europa.eu/transparency/regrin/welcome.do?locale=en\#en
} 


\section{The European Citizens' Consultation, a transformative process}

\subsection{The renewal of institutional communication and the ECC}

The consultation process carried out by the ECC is quite different. These differences result from the strategies in which eParticipation projects are embedded. In the case of the ECC, the online mechanism is rather seen as a communication tool, than as a policy instrument.

In 2005, the Barroso Commission adopted an Action plan to improve communicating Europe, which emphasized the interest of creating two-way channels of communication, in order to allow for exchanges between citizens and institutions at the European level. At a time when the renewal of the communication systems of the institutions is under way, interactive sites are put online with the aim of offering European citizens new spaces of expression.

The same year, the DG Communication initiated the Plan-D for Democracy, Dialogue and Debate. One of its aims was to experiment with new methods of consultation apt to create spaces of transnational exchanges. Six European projects were financed, and amongst them the first European Citizens' Consultation, which took place in 2007.

In 2009, a second edition was launched. The project was co-funded by the DG Communication under its Debate Europe Programme (2008), and was managed by a consortium of European civil society organizations, led by the King Baudouin Foundation. The ECC 2009 used a new formula: the idea was to articulate an online phase with an offline phase, in order to achieve the first panEuropean consultation involving the 27 Member States of the Union. A European platform was put online, and deployed through 28 national sites (one per country and two for Belgium, one in French and the other in Flemish). European citizens were invited to login to their national site in order to inform themselves, to participate in debates, to propose recommendations, and to vote for those that they considered most relevant with respect to the general theme of the consultation (i.e., "What can the EU do to shape our economic and social future in a globalised world?").

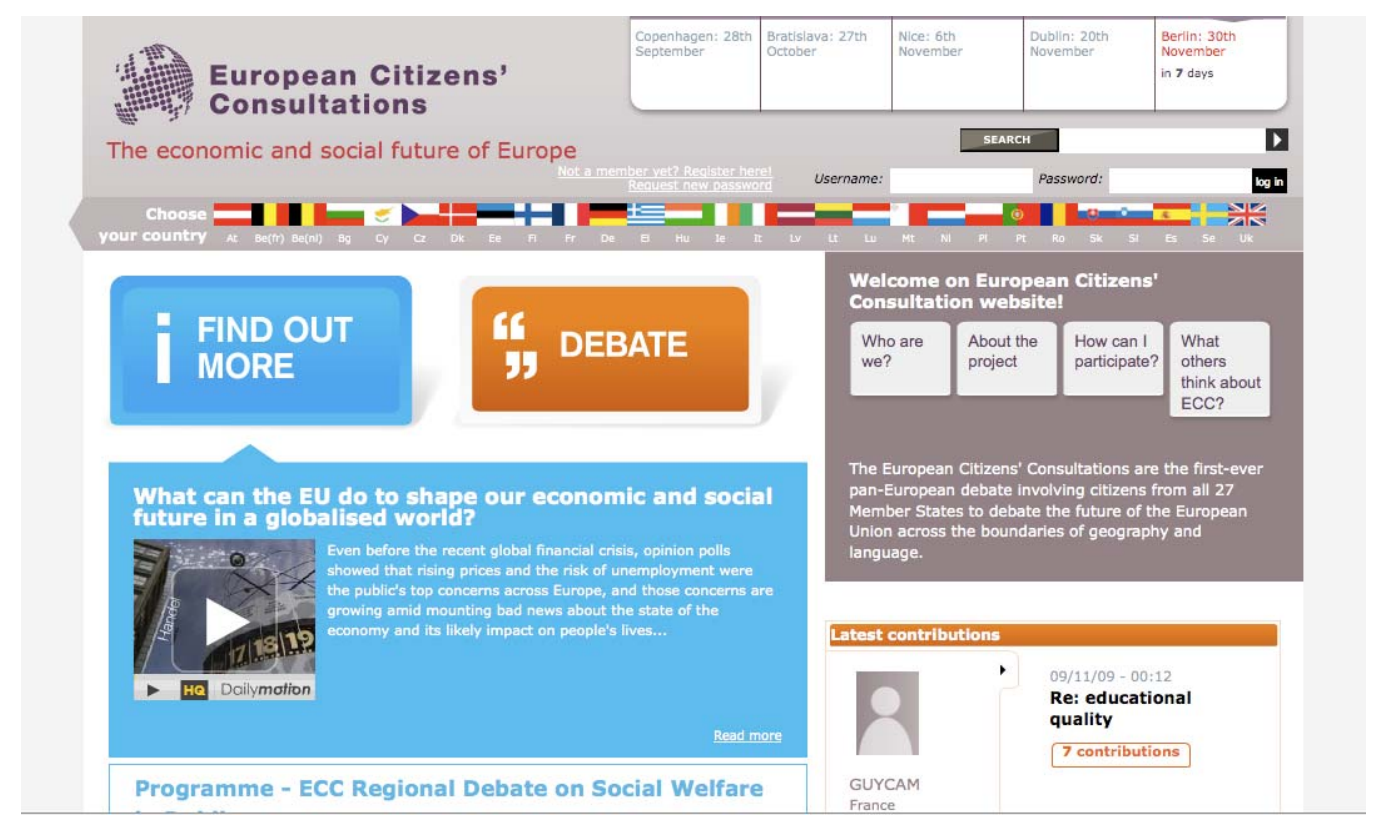

Figure 1: The ECC website (http://www.european-citizens-consultations.eul, May 2010)

Face-to-face debates were then organized at the national level. In each country, a hundred citizens were chosen by opinion-poll institutes in order to set up panels which were representative of each national population. The notion of representativeness is important here: the organizers 
wished to end up constituting a European public opinion by aggregating the national opinions. During the course of these debates, the 10 propositions which had received the most support on the national sites were presented to the panels, who then chose to adopt them or not (the wishes expressed by the votes on the sites did not have any binding power for the next stages of the process). The panels then drafted in their turn a set of recommendations which were voted upon online at the European level (by the participants in the face-to-face debates, who had access codes to a restricted part of the ECC site). The 15 propositions which received the most votes were then selected for a European Citizens' Summit meeting which took place on May 10th 2009 in Brussels. The citizens who were present, selected amongst those who had participated in the face-to-face debates, rewrote them to produce 15 recommendations, which were then submitted in the form of a report to a panel of European decision-makers on the occasion of a debate at the Belgian Ministry of Foreign Affairs on May 11th. This panel consisted of the President of the Commission, the President of the Parliament, and the representatives of the different political groups represented in the Parliament.

\subsection{Learning European citizenship}

The proclaimed aim of the ECC was to influence decision-makers by the formalisation of a European public opinion on Community issues (an "opinion" which is open to discussion, since it was constructed by the aggregation of national opinions, the online and offline debates being confined to the scale of Member States). According to the project presentation on its website, the ECC was also an experiment of new kinds of policy instrument. In this regard, its main interest resides in the process adopted.

By developing the first pan-European citizens consultation, the project had the aim of developing transnational spaces of debate (an element which is also open to discussion, for the same reasons), which involved citizens from different Member States in a procedure promoting the awareness of a European identity and citizenship.

To take up a typology established by S. Smith (2008), one can make a distinction in terms of eParticipation between those procedures which involve an instrumental participation, and those which involve a transformative participation. The sites with an instrumental bearing are those which are mobilized in the framework of specific public policies, and which are evaluated in view of their results, as in the case of Your Voice in Europe. By contrast, the main interest of the transformative sites resides in the very process that they organize: through their participation, the participants can develop a certain sensitivity to European policy issues, and can thus initiate themselves into a form of European citizenship. The ECC platform corresponds rather to this second type.

During the ECC process, participants are engaged in a pan-European debate (and not in a transnational one), where they are invited to learn about important European stakes. As they exchange and vote on political issues, they are acting as citizens. During the debates and the Citizens' Summit, they are interacting with European decision-makers (in theory). The ECC is thus an experiment of a new format of political mediation, where participants assume a role of citizen on a European level. In this regard, the ECC is a transformative process. For the institutions, this kind of project presents great interests in terms of institutional communication, as it stages the building of a European citizenship and promotes the European identity by new means.

Another distinction is made by S. Smith, A. Macintosh and J. Millard (2009) in terms of outcomes of eParticipation projects. They distinguish operational outputs (which are generated through the construction of eParticipation tools), specific objectives (related to the benefits of the project for stakeholders), and general objectives (societal objectives linked to public values). Based on this typology, one can say that the general objectives of Your Voice in Europe are related to institutional transparency and openness, while the ECC general objectives are linked to the building of a European public sphere and the development of a culture of active citizenship. In the first case, the main outcomes are of benefit for the Commission, and in the second one, they are of benefit for the citizens. 
Our two case studies are online consultations, whose first purpose is to involve citizens in political processes at a European level. But their designs are very different. As S. Wright and J. Street stated in the context of online discussion forums (2007), the design of eParticipation websites is closely linked to the political strategies in which they are involved. In this regards, they carry out specific models of citizenship. Your voice in Europe is a policy instrument which benefits from an institutional recognition as a mean to regulate and broaden the scope of expertise and lobbying. The European Citizens' Consultation is a communication tool that involve citizens in order to make them develop a European sensitivity. As we shall see, both models have problems attracting "ordinary" citizens.

\section{The actors involved: in search of the European citizen}

\subsection{Your Voice in Europe: organized civil society vs. citizens ?}

In the framework of the consultations carried out on Your Voice in Europe, the DGs have the benefit of a certain degree of independence in the administration of the consultations that they organize. The process is normalized: the questionnaires which serve as the basis for the work must be drafted in accordance with strict criteria: the DGs must provide information concerning the duration of the consultation (the minimum duration is theoretically 8 weeks), and they are obliged to provide some feedbacks to the actors they have consulted. However, the DGs take the initiative for setting up each consultation, choosing the theme, and the sort of public they wish to associate with. In this way, some DGs develop privileged relations with NGO platforms and refuse to make their consultations public, even if they are encouraged to do so by the Commission.

On the site, different types of public are mentioned: "public", "stakeholders", "European citizens", or yet again "interested parties". The Commission gives relatively broad definitions of these categories, and it is difficult to identify simply by the label what sorts of actors actually participate. A more revealing factor is the actual theme of the consultation. Indeed, some of these themes are so specialized that they imply a high degree of expertise on the part of the participants. On the other hand, although the front page of the site is available in each of the 23 official languages of the European Union, the pages dedicated specifically to each of the consultations, and the documents which are made available on these pages, are often only translated into one or two languages. In every case, English prevails. Having a certain level of knowledge concerning the question addressed by the consultation, and proficiency in English, even if they are not absolutely necessary, are at least highly useful when entering Your Voice in Europe. The configuration of the site, and the procedure which it organizes, thus present several obstacles to the participation of "ordinary" or "lay" citizens.

In 2009, the French Economic, Social and Environmental Council (CESE) published a study of the online consultations carried out by the Commission, for the months of September 2008 and March 2009. Over this period, 31 consultations took place, producing 5553 replies. The breakdown of the origins of the contributions was as follows: $18.5 \%$ Public Authorities, $46.5 \%$ Civil Society Organizations, $7.3 \%$ Research Centres, Universities and "think tanks", 14.2\% individual citizens, and $13.5 \%$ businesses. 


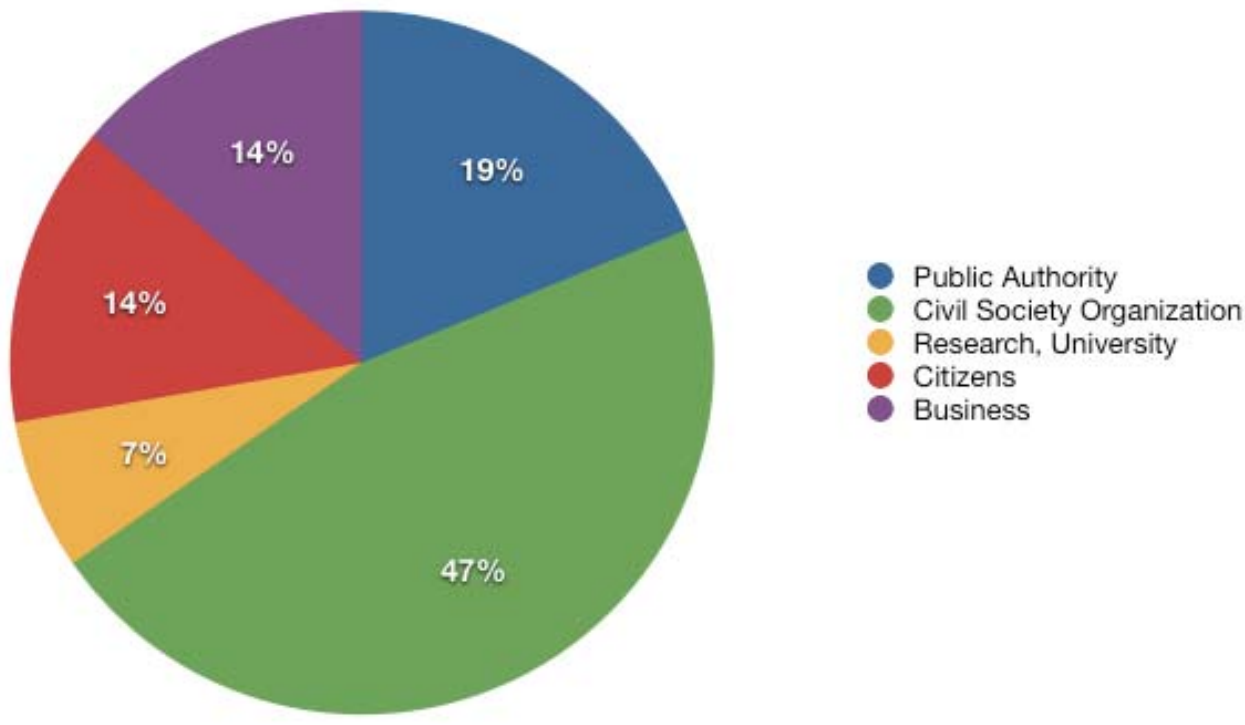

Figure 2. Origin of the contributions to the Commission consultations for the months September 2008 and March 2009 (Conseil Economique, Pour une participation active de la société civile aux consultations publiques européennes, 2009, p. 44).

If the "European citizen" as an individual plays a small part in these consultations, it is rather the civil society organizations which are the predominant partner. The definition given by the Commission of European "civil society" is quite large, and includes:

"trade unions and employers' organisations ("social partners"); non-governmental organisations; professional associations; charities; grass-roots organisations; organisations that involve citizens in local and municipal life with a particular contribution from churches and religious communities." (European Commission, White Paper on European Governance, 2001, p.14).

The high level of participation of civil society organizations can be partially explained by the very history of Your Voice in the Europe. As we have seen, since its beginning, it was also related to a strategy of regulation of the relationships between the Commission and interest groups. In this case, the participants of the Commission consultation are seen as sources of expertise or impact analysis.

The European citizen is involved in the process of consultation by means of associations, interest groups, and various organizations. The latter are recognized as providing a mediation between the Commission and "ordinary citizens", to the extent that they represent the wishes of their members. They can be considered as transnational segmented publics, as they are defined by E.O. Eriksen (2005), i.e. Europe-wide political networks of individuals concerned by specific issues. The main problem of this kind of participation becomes the absence of a link between these segmented publics and a general public at a European level (Bouza Garcia, 2009).

Moreover, Your voice in Europe embodies an aggregative model, as the relation with the Commission occurs "one to one", by sending a contribution directly by email. The overall contribution results from the sum of individual contributions. There is no deliberation on the site, as there is no online forum. This structure of the exchange, in the style of a private communication, fits with the representation of interest, the expression of sector-based claims, or the submission of expertise. We can notice here a link between the structure of the exchange on the website, the strategy in which it is embedded, and the actors who participate. 


\subsection{The ECC: the weight of online activism}

By contrast, the ECC platform makes a specific attempt to involve the "ordinary" citizen, in two ways: firstly by allowing the participation of a large number of persons during the online phase; and then by having recourse to representative panels of individuals during the phase of national meetings. The online platform is divided into 28 sites, thus allowing European citizens to participate and to exchange in their own language. By contrast with Your Voice in Europe which embodies an aggregative model, the ECC platform embodies both a deliberative and an aggregative model: the participants must discuss amongst themselves and vote for recommendations at a national scale ; their preferences are then aggregated at a European Scale. The combination of these two models leads to a high complexity of the ECC process, that has complicated its implementation and has decreased the participants' incentives for deliberation (Karlsson, 2010).

Moreover, during the online phase, the mobilization of activist networks has been an obstacle to the participation of individuals, as it influenced the recommendations vote.

The operational mode is the following: leading members of the networks post on the ECC site one or more recommendations related to the themes around which they are mobilized. The URL address of the page which hosts the recommendation is then sent to the whole network by means of mailing-lists, online groups or social networks. The militants are prompted to register themselves on the site and to vote for the recommendation. The capacity of these networks to mobilize their members is such that in France, five out the ten propositions which obtained the most votes were produced by these activist networks.

There are three clues which lead to this conclusion. Firstly, I have conducted a search for the URL addresses of pages which harbour these propositions. In each of the five cases, I have found them, integrated with a message encouraging a vote, on the sites, the blogs or online groups which are openly linked to militant associations. Secondly, analysing the statistics provided by the ECC platform (with Google Analytics), I notice that the vast majority of votes were cast over a very short time-period, the most often 24 or 48 hours. Thirdly, the majority of the visits to the ECC pages had an external origin to the ECC platform, which indicates that the web users arrived directly there by clicking on a link, and not by navigating on the site. Web users came on specific pages by clicking on links, these links have been found in fora and online groups related to activist networks, and the propositions hosted on these same pages were voted by a large number of web users in a short time-period. The accumulation of these three clues indicates that during the voting phase, collective actions structured on the basis of external networks of sites and platforms have targeted the ECC platform with the aim of helping certain propositions to gain as many votes as possible.

This tendency was observed on most of the European sites of the ECC. Certain networks even organized transnational actions, inviting their members to go and vote on similar propositions on a number of different ECC sites. Thus, I have observed this sort of Europe-wide mobilization on subjects such as Esperanto, the legalisation of cannabis, or animal rights.

The influence of the activist networks has been decisive during the voting phase of the recommendations. The "ordinary citizens" were thus outweighed by "organized citizens", who undertook structured actions which succeeded in promoting interests related to the organization they belonged to.

Although this analysis must be put into perspective, to the extent that the over-representation of these activist networks is in part due to the weak global participation in this platform, this example does pose the question of the real possibilities for mobilizing European citizens as individuals during online consultations. More precisely, it emphasizes the weaknesses of this participatory mechanism as a tool for promoting the emergence of a genuine "general will" at the scale of the Union; in this particular case, the "special interests" represented by the transnational militant networks occupy the terrain by a massive capacity of mobilization.

We have noticed in the first parts of this paper an adequacy between the structure of the exchange on a website, the political strategy in which it is embedded, and the actors who are called on to participate. But the last example shows that web users develop their own strategy of 
appropriation and can thus divert the initial use of a website. As we shall see, these diversions, because they can be considered as the manifestation of the users creativity, can have positive effects with regard to the goals of the project.

\section{The effects of online participatory mechanisms}

\subsection{Collateral effects can produce European dynamics}

Concerning online participatory mechanisms, one can distinguish between desired effects (whether they are achieved or not), and collateral effects.

Let us take the example of the ECC. As we have seen, the online debates were divided according to the nationality of the participants, and it was not possible for a web user from one Member State to exchange directly with a user from another Member State on his own national site. This structural impossibility of engaging in transnational exchanges renders the objective of constituting an online Europe-wide public sphere null and void.

The mobilization of militant networks, while it influenced the voting phase, did also allow for the constitution of a transnational public, to the extent that the participants, independently of their nationality, grouped together around specific themes in order to lead European actions. These participants overcame the portioning of the debates and, by doing so, they also produced a European dynamic, by structuring spaces of exchange across the frontiers of Member States.

Although the mobilization of these networks was a non-desired effect, paradoxically enough it actually contributed to achieve one of the objectives of the project. The deviation from the intended use of the site favours transnational communication, even if the ECC platform was not the place for these exchanges (the activists used mailing list, online groups and social networks to coordinate their actions). This example shows that uses which are not foreseen by the authors of these mechanisms can nevertheless have "beneficial" effects on the process. As shown by L. MonnoyerSmith (2006) in another context, this point stresses the importance of leaving a certain amount of freedom in the way the users will appropriate these sites. Therefore, the technical structure of these sites has to be flexible in order to guarantee spaces of innovative expression for users. This is particularly important in a transnational context, as the participants of such processes belong to various political cultures. We could talk here of "spaces of creative action", that can be places where these political and technical cultures are mixed in a certain way in order to produce European dynamics and to favour the emergence of transnational publics.

\subsection{The impact on the decision-making process}

Concerning another objective of the consultation, which was to influence decision-makers by submitting a report containing the recommendations elaborated by the citizens, it is difficult to make a definite judgement as to the success or failure of the initiative. The meeting which took place between the panel of European political figures and the participants during the European Citizens' Summit, described above, raised as many questions as it answered. There was a political debate between decision-makers and participants, but there was no guarantee that the recommendations would actually be taken into account. In this model, there is no official link between the consultation and the decision-making process, the recommendations do not benefit from a binding effect, and the institutions do not have to provide feedbacks to the participants.

By contrast, the main originality of the consultations organized by the Commission resides in their legally defined articulation with traditional modes of governance.

Thus, the General principles and minimum standards for consultation of interested parties stipulate that the consultations carried out by the DGs of the Commission should intervene upstream of the legislative process so that, as I indicated at the beginning of this article, in the course of future initiatives the Commission would be able to take into account the different opinions and interests involved. The role of the actors convened is here to provide the Commission with information concerning the acceptability of these policies, but also to make it possible for the 
Commission to associate these actors in defining the objectives, in identifying the methods to be set up, and the tools to be mobilized in order to attain these objectives. It is more a question of enabling the actors consulted to participate in the preparation of the decision, rather than taking part in the decisional process itself.

The legal definition of the insertion of the participatory mechanism Your Voice in Europe in the decision-making process should favour a strong link between consultation and decision. However, the non-binding aspect of these consultations is also written into the texts. Indeed, the Commission states explicitly in the definition of its General principles and minimal standards that these procedures are not legally binding.

The organizations and the citizens express themselves, but the DG at the origin of the consultation reserves itself the right to consider whether a contribution is relevant or not. However, to the extent that the DG is obliged to provide feedbacks to the participants concerning the way in which the contributions will be taken into account, these contributions do exert a certain pressure on the institution, and thus on the decisions to be taken.

We can notice here that an official recognition of an eParticipation tool leads to the recognition of the public that gathers around that tool, as the institution has to justify its choice in front of this public. The recognition of Your Voice in Europe as a policy instrument implies the establishment of a normalized political mediation between institutions and a European public. Even if this public does not benefit from a binding power, the accountability of the institution leads it to consider the participants as legitimate political actors.

\section{Conclusion}

eParticipation at the European level follows different pathways. Even if they have similar objectives, like involving citizens in the European political decision-making process as we have seen in the paper, procedures and arrangements employed vary significantly.

These differences result first from the strategies within which the eParticipation projects are embedded. Whether it is a question of reforming the European governance, or of developing twoway channels of communication, the issues at stake and the short-term objectives are different. Thus, eParticipation websites carry out specific models of political practices, in relation with these strategies.

The actors called upon vary and both models have difficulties in mobilizing the "ordinary" citizens. Nevertheless they are the source of legitimacy for democratic decision-making. The aggregative model fits with the mutation of lobbying and expertise practices at the European level, and as such civil society organizations become active players. Their legitimacy results from the citizens or the interests that they represent. In the deliberative model, the massive capacity of mobilization of activists networks can outweigh the expression of the "ordinary" citizens. Once again, the "organized" citizen prevails.

A third difference results from the articulation of these procedures with traditional tools of European governance. The use of eParticipation arrangements as communication tools tends to create a divide between decision and deliberation, whereas their acceptance as policy instruments suggests a binding effect on the decision-making process. As I stated, the official recognition of an eParticipation tool implies the establishment of a standardised political mediation between an institution and the public, and doing so, to a recognition of individuals and organizations that gather around this tool as legitimate actors. An official status and a legal framework for these tools in the decision-making process are thus part of the conditions of their sustainability.

However, these mechanisms must also exhibit a certain degree of openness in the format of the procedures that they instigate: the technology must not constrain uses too tightly, and eParticipation websites should provide a space where users can freely express their creativity. It is from these "spaces of creative action" that unforeseen effects can arise, which could produce European dynamics and lead to the constitution of transnational publics. The pathway for durable 
online participatory mechanisms at the European level is sketched somewhere between the requirement of an official recognition of these tools, and the guarantee of a weak technical constraint of their uses.

\section{References}

\section{Books and articles}

Bouza Garcia, L. (2009). Can segmented publics foster a general public sphere in the EU? An example from the consultation practices of the European Commission. Observatorio Journal, 3(2), 169-185. Retrieved July 9, 2009, from http://www.obercom.pt/ojs/index.php/obs/issue/view/15

Dalakiouridou E., Tambouris E. \& Tarabanis K. (2009), Mapping the state of play in eParticipation in the EU, European eParticipation Deliverable 1.4c , Retrieved January 25, 2010, from http://www.european-eparticipation.eu/.

Eriksen, E.O. (2005). An emerging European public sphere, European Journal of Social Theory, 8(3), London: Sage Publications, 341-363.

Karlsson M. (2010) , A Panacea for Pan-European Citizen Participation? Analysis of the 2009 European Citizen Consultations, in E. Amna, New forms of citizen participation : normative implications, Baden-baden : Nomos, 97-112.

Lascoumes, P., \& Le Galès, P. (2004), Gouverner par les instruments, Paris: Presses de Sciences Po.

Monnoyer-Smith, L. (2006), Etre créatif sous la contrainte. Une analyse des formes nouvelles de la délibération publique. Le cas Ducsai, Politix (Dispositifs participatifs), 75, 75-101.

Saurugger, S. (2006), Les groupes d'experts, une porte d'entrée de la société civile dans le processus décisionnel ?, in C. Belot \& B. Cautres (Eds.), La vie démocratie de l'Union Européenne, Paris: La Documentation Française, 47-64.

Scharpf, F. W. (1999), Governing in Europe. Effective and Democratic? Oxford/New York : Oxford University Press.

Smith,S., Macintosh, A. and Millard J. (2009), Major factors shaping the development of eParticipation, European eParticipation Deliverable1.1c, Retrieved January 25, 2010, from http://www.european-eparticipation.eu/

Smith, S. (2008), Main benefits of eParticipation developments in the EU, European eParticipation deliverable 1.3a, Retrieved February 23, 2008, from http://www.european-eparticipation.eu/

Wright S. \& Street J.(2007), Democracy, deliberation and design : the case of online discussion forums, New Media Society, 9(5), London : Sage Publications, 849-870.

\section{Official documents}

Conseil Economique, social et environnemental (2009), Pour une participation active de la société civile aux consultations publiques européennes, Journal Officiel $n^{\circ} 2009-22$.

European Commission (2000), Reforming the Commission. A White Paper, COM(2000) 200 final.

European Commission (2001), European Governance. A White Paper, COM(2001) 428 final.

European Commission (2002), Towards a reinforced culture of consultation and dialogue - General principles and minimum standards for consultation of interested parties by the Commission, COM(2002) 704 final.

European Commission (2005a), Action plan to improve communicating Europe by the Commission, SEC(2005) 985 final.

European Commission (2005b), The Commission's contribution to the period of reflection and beyond: Plan-D for Democracy, Dialogue and Debate, COM(2005)494 final.

European Commission (2006), i2010 eGovernment Action Plan : Accelerating eGovernment in Europe for the Benefit of All, $\operatorname{COM(2006)} 173$ final.

European Commission (2007), Follow-up to the Green Paper European Transparency Intiative, COM(2007) 127 final.

European Commission (2008), Debate Europe-Building on the experience of the Plan D for Democracy, Dialogue and Debate, $\operatorname{COM}(2008) 158$ final.

\section{Websites}

European Citizen's Consultation. http://www.european-citizens-consultations.eu/

Your Voice in Europe. http://ec.europa.eu/yourvoice/

Register of Interest Representatives. https://webgate.ec.europa.eu/transparency/regrin/welcome.do?locale=en\#en 


\section{About the Author}

\section{Romain Badouard}

Romain Badouard is a PhD candidate at the University of Technology of Compiègne (France). His research addresses the implementation of e-governement tools within European institutions, and focuses on the ways in which these give rise to new modes of interaction between institutions and citizens. He is also a member of the Vox Internet research program, financed by the National Agency for Scientific Research in France, focused on political and technical dimensions of Internet governance. 